\title{
PEMBELAJARAN MATEMATIKA: STRATEGI PEMBELAJARAN 'BLACK TEA' DALAM MEMINIMALISIR LEARNING OBSTACLE SISWA
}

\author{
Muhamad Galang Isnawan ${ }^{1}$, Sudirman $^{2}$ \\ ${ }^{1}$ Universitas Nahdlatul Wathan Mataram, Jl. Kaktus No.1-3, Gomong, Kec. Mataram, Kota \\ Mataram, Nusa Tenggara Bar. 83126, galangisna19@gmail.com \\ ${ }^{2}$ Universitas Wiralodra, Jln. Ir. H. Juanda Km 3, Indramayu, sudirman@unwir.ac.id
}

Diterima 2 Juni 2020, disetujui 05 Oktober 2020, diterbitkan 30 Oktober 2020

Pengutipan: Isnawan, M.G \& Sudirman. (2020). Pembelajaran Matematika: Strategi Pembelajaran 'Black Tea' dalam Meminimalisir Learning Obstacle Siswa. Gema Wiralodra, Vol 11, No 2, Hal 274-291, Oktober 2020

\begin{abstract}
ABSTRAK
Pembelajaran matematika dalam implementasinya mengalami masalah dalam hal learning obstacle yang dialami siswa cenderung lebih tinggi. Berkaitan dengan hal tersebut, ada salah satu strategi pembelajaran yang diharapkan mampu mengurangi learning obstacle yang dialami siswa, yaitu strategi pembelajaran 'Black Tea'. Strategi ini didasarkan pada filosofi interpretive and critical pedagogy. Adapun beberapa langkah pembelajaran dalam strategi pembelajaran tersebut adalah: (1) guru melakukan analisis pendahuluan mengenai learning obstacle apa saja yang dialami siswa dalam pembelajaran matematika; (2) guru sengaja melakukan kesalahan pada saat proses pembelajaran; (3) guru memastikan siswa menyadari bahwa guru melakukan kesalahan; (4) guru meminta siswa untuk mengkonfirmasi perbaikan yang diberikan; dan (5) guru bersama-sama dengan siswa membuat kesimpulan perbaikan atas kesalahan yang dilakukan guru.

Kata Kunci: Learning Obstacle, Pembelajaran Matematika, Strategi Pembelajaran 'Black Tea'
\end{abstract}

\section{PENDAHULUAN}

Bagi sebagian besar siswa, mata pelajaran matematika adalah mata pelajaran yang paling membosankan, menakutkan, dan tergolong sangat sulit (Zan \& Martino, 2007). Siswa beranggapan bahwa mempelajari matematika tidak memiliki manfaat langsung dalam kehidupan sehari-hari, kecuali matematika pada level-level dasar, seperti operasi hitung dasar (kali, bagi, tambah, dan kurang). Sebagai contoh, siswa menganggap materi integral, deret, fungsi, dan himpunan sebagai materi yang kurang bermanfaat dalam implementasi kehidupan seharihari. Siswa lebih tertarik belajar bahasa inggris dibandingkan belajar matematika karena bahasa inggris bisa digunakan dalam berinteraksi dengan orang luar negeri dan untuk kepentingan studi ke luar negeri. Hadirnya matematika di sekolah juga menurut sebagian siswa dianggap sebagai sesuatu yang hanya menambah beban dan menambah tingkat kecemasan bagi siswa itu sendiri (Telkamp, 1981).

Hadirnya persepsi yang buruk terhadap matematika tersebut kemudian menjadi kendala dalam pembelajaran matematika. Fakta menunjukkan bahwa 
siswa sebagian besar hanya mampu memahami matematika dalam level standar, sedangkan untuk level lanjutan sebagian besar siswa tidak mampu menjangkaunya (Hanushek, Peterson, Woessmann, \& School, 2010). Hasil PISA 2012 juga mengungkapkan bahwa rata-rata kinerja matematika siswa di kawasan Asia Tenggara berada di bawah rata-rata, termasuk Indonesia (Hwang, Choi, Bae, \& Shin, 2018). Bahkan, diperjelas bahwa kemampuan pemecahan masalah matematika siswa di Indonesia, khususnya sekolah pada tingkat sekolah menengah masih tergolong sangat lemah (Priyani \& Ekawati, 2018). Hal ini kemudian mengindikasikan bahwa matematika, terutama di Indonesia merupakan salah satu mata pelajaran yang sulit sehingga kompetensi siswa pada mata pelajaran tersebut tergolong sangat rendah.

Salah satu faktor yang menyebabkan rendahnya kompetensi siswa dalam matematika adalah adanya kecenderungan guru untuk menerapkan pendekatan atau strategi pembelajaran yang kurang tepat, seperti pembelajaran konvensional. Strategi pembelajaran yang diterapkan guru pun cenderung monoton sehingga siswa menjadi bosan karena hanya disajikan materi, diberikan contoh soal, dan diakhiri dengan pemberian latihan soal (Surya, Putri, \& Mukhtar, 2017). Mengubah kebiasaan guru cenderung sangat sulit karena membutuhkan keinginan yang kuat dan kemauan guru untuk belajar dan berubah. Selain itu, siswa pun haruslah terbuka untuk berubah seiring dengan perubahan strategi pembelajaran guru. Siswa harus mampu mengikuti instruksi guru dengan mengubah kebiasaan belajar lama di kelas yang sering dilakukan sebelumnya (Boyd \& Ash, 2018). Pada intinya, guru memegang peranan yang sangat penting dalam mengembangkan kompetensi matematika yang dimiliki siswa (Hanushek \& Rivkin, 2006). Seorang guru haruslah mampu memanfaatkan dan memperhatikan potensi awal yang dimiliki siswa dalam memilih strategi pembelajaran yang tepat untuk diterapkan di kelas.

Jika merujuk pada kompetensi capaian, baik yang berlaku di Indonesia (Kurikulum 2013), maupun yang berlaku secara internasional, maka ketercapaian indikator pembelajaran yang ada di Indonesia tergolong tidak komprehensif. Banyak kompetensi yang harus dimiliki siswa dalam pembelajaran matematika tetapi tidak tercantum langsung dalam indikator pembelajaran pada Kurikulum 
2013, seperti: kemampuan komunikasi matematika, kemampuan koneksi matematis, kemampuan representatif, dan kompetensi-kompetensi lain yang termasuk ke dalam high order thinking skill (HOTS) (Oktiningrum, Zulkardi, \& Hartono, 2016; Rohendi \& Dulpaja, 2013; Stacey, 2011).

Selanjutnya, bagaimana cara mengembangkan kompetensi matematika siswa? Hal inilah yang menjadi pekerjaan rumah bagi semua orang yang terlibat dalam dunia pendidikan, terutama guru matematika. Mengapa guru matematika? Hal ini disebabkan karena guru matematika merupakan unsur sekolah yang berinteraksi dengan durasi waktu terlama dengan siswa di sekolah. Siswa menghabiskan hampir 90\% waktunya di sekolah dengan guru. Oleh karena itu, guru matematika harus mampu menjadi fasilitator yang mampu membantu dan memberikan pengalaman belajar terbaik bagi siswa. Guru matematika harus mampu membantu siswa dalam mengkontruksi konsep matematika yang dipelajari. Guru matematika harus mampu membantu siswa dalam menyelesaikan permasalahan-permasalahan matematika kontekstual dengan strategi pemecahan masalah yang terbaik. Guru matematika harus mampu memanfaatkan semua kompetensi dan pengalaman awal yang dimiliki siswa agar pembelajaran menjadi lebih berkualitas dari sebelumnya (van de Pol, Volman, \& Beishuizen, 2010). Bahkan, guru harus mampu memanfaatkan teknologi informasi dalam kegiatan pembelajarannya (Niess, 2005).

Berdasarkan uraian di atas, maka bukan hanya siswa saja yang harus memiliki kompetensi yang banyak dalam belajar matematika, melainkan juga guru matematika. Tercatat, seorang guru haruslah memiliki beberapa kompetensi, seperti kompetensi profesional, kompetensi pedagogik, kompetensi kepribadian, dan kompetensi sosial (Selvi, 2010). Guru matematika yang baik haruslah mampu menyusun kegiatan pembelajaran dengan memperhatikan siswa sebagai variabel utama dalam menentukan strategi belajar yang akan diterapkan di kelas. Guru matematika haruslah mengetahui kemampuan awal yang dimiliki siswa dengan baik. Guru matematika haruslah mampu memetakan titik lemah siswa dalam matematika untuk kemudian melakukan perbaikan pada titik lemah tersebut. Atau dengan kata lain, guru matematika haruslah mampu memberikan perhatian lebih pada kelemahan yang dimiliki siswa dalam pembelajaran matematika. Apakah 
kelemahan tersebut berkaitan dengan operasi hitung? Apakah kelemahan tersebut berkaitan dengan pemahaman konsep? Hal inilah yang kemudian harus dikaji oleh guru sebelum memulai dan memilih strategi pembelajaran yang tepat.

\section{PEMBAHASAN}

\section{Strategi Pembelajaran 'Black Tea'}

Ada salah satu strategi pembelajaran yang menurut penulis bisa diterapkan oleh guru di sekolah. Strategi ini tergolong sangat baru karena untuk pertama kalinya diperkenalkan oleh penulis pada tulisan ini (berdasarkan pengalaman mengajar matematika di sekolah). Meskipun, pelaksanaan strategi tersebut sudah pernah dilakukan guru di senior high school pada tahun 2018. Apakah strategi pembelajaran tersebut? Strategi pembelajaran tersebut adalah strategi pembelajaran 'black tea'. Strategi pembelajaran 'black tea' sebenarnya merupakan strategi pembelajaran yang sudah sering dilaksanakan guru di sekolah. Akan tetapi, strategi tersebut hanya saja kurang diperhatikan dan dimanfaatkan oleh guru matematika secara maksimal. 'Black tea' sebenarnya singkatan dari 'black teacher'. Mengapa black teacher? Black dalam kehidupan sehari-hari biasanya identik dengan sesuatu yang kelam, black sering kali dihubungkan dengan gelapnya malam, black juga sering dikaitkan sebagai sesuatu kesalahan yang pernah dilakukan, dan black juga biasa dikaitkan dengan tindakan kriminal. Bahkan, beberapa negara tertentu, seperti US mengaitkan "black" sebagai identitas dari kelompok tertentu (Maylor, 2012). Padahal, jika merujuk pada makna sebenarnya, 'black' pada dasarnya adalah salah satu jenis warna. Akan tetapi, dalam penggunaannya secara konotasi, 'black' biasanya dihubungkan dengan hal-hal yang negatif atau buruk. 'Black teacher' atau sebut saja 'black tea' untuk sementara bisa diartikan sebagai kesalahan-kesalahan yang biasa dilakukan guru selama kegiatan pembelajaran.

Akan tetapi, sebelum membahas lebih lanjut mengenai 'black tea', terlebih dahulu akan dijelaskan beberapa hal penting mengenai alasan pemilihan istilah 'black tea'. Mengapa penulis tidak memilih istilah singkatan 'BT' sebagai 'black teacher'? Mengapa penulis cenderung lebih memilih singkatan 'black tea'? Hal ini disebabkan karena ' $B T$ ' dalam bahasa sehari-hari di Indonesia sebagai bosan, sedangkan 'black tea' dalam arti yang sebenarnya merupakan salah satu dari 
sekian banyak jenis teh yang ada di belahan dunia. Black tea merupakan salah satu jenis teh yang kandungan polifenolnya bermanfaat untuk mencegah penyakit kanker. Polifenol yang terkandung dalam black tea tersebut mampu menjadi antioksidan yang bisa mencegah munculnya sel kanker dalam tubuh seseorang. Mengingat akan manfaat black tea ini, maka penulis lebih memilih menggunakan singkatan 'black tea' untuk 'black teacher' dari pada istilah 'BT'. Penyakit kanker yang dimaksudkan dalam hal ini kemudian bisa dianalogikan sebagai masalahmasalah yang dialami siswa dalam pembelajaran (Henning et al., 2004). Penulis juga khawatir jika istilah yang digunakan adalah 'BT', kecenderungan yang terjadi justru strategi pembelajaran tersebut menjadi membosankan bagi siswa. Diharapkan dengan filosofi ini akan mampu menjadi acuan atau langkah awal bahwa penerapan strategi pembelajaran 'black tea' akan mampu mencegah munculnya permasalahan yang dialami siswa pada pembelajaran matematika sehingga kompetensi siswa pun menjadi berkembang secara maksimal.

Selanjutnya, ada beberapa pertanyaan yang harus dijawab. Pernahkah guru mengalami kesalahan dalam pembelajaran? Apa saja jenis kesalahan tersebut? Pernahkah guru menyadari bahwa siswa terkadang menyadari kesalahan tersebut? Pernahkah siswa mencoba mengkoreksi guru? Ada beberapa kemungkinan jawaban dari pertanyaan tersebut, antara lain: semua guru pasti pernah mengalami kesalahan dalam pembelajaran, seperti: guru salah dalam menulis simbol dalam matematika, guru salah dalam menulis nilai tertentu pada suatu variabel, guru salah dalam membubuhkan tanda operasi. Bahkan, guru juga pasti pernah mengalami kesalahan dalam pemahaman konsep (meskipun kecil frekuensi kejadiannya). Perlu diketahui juga bahwa siswa terkadang juga menyadari kesalahan tersebut dan siswa pun berusaha untuk mencoba mengingatkan atau mengoreksi guru berkaitan kesalahan yang dilakukan, seperti siswa memberitahukan kepada guru bahwa nilai atau operasi yang digunakan keliru.

Ada respon menarik yang biasanya digunakan guru ketika siswa mengoreksi, seperti: “oh, itu sengaja, untuk menguji kalian saja, apakah kalian memperhatikan atau tidak," biasanya guru sambil senyum kecil dan siswa pun menimpali senyum tersebut dengan gelak tawa di kelas. Respon tersebut juga 
biasa dimanfaatkan guru sebagai suatu strategi dalam mengelola kelas agar tensi kelas tidak terlalu tegang (Dunbar, 2004). Beranjak dari hal tersebut, ada satu poin penting yang unik dan bisa dipetik untuk kemudian dikaji oleh guru, yaitu siswa ternyata cenderung lebih memperhatikan guru ketika ada kesalahan yang dilakukan guru pada saat proses pembelajaran. Beberapa siswa yang biasanya tidak terlalu aktif di kelas akan cenderung memberikan respon ketika guru melakukan kesalahan.

Banyak respon yang sebenarnya bisa dilakukan guru pada saat kesalahan tersebut terjadi, seperti meminta siswa untuk membaca buku dan memastikan apakah konsep tersebut benar-benar salah atau tidak, dan bisa dijadikan sebagai pengalaman belajar baru bagi siswa. Siswa pun secara otomatis akan mencoba membuka buku, baik buku paket, maupun buku catatan untuk mengkonfirmasi atau memastikan apakah guru benar-benar melakukan kesalahan atau tidak. Siswa pun bisa juga saling mengkonfirmasi dengan siswa yang lain untuk memastikan kesalahan tersebut. Sampai dengan saat ini, hal inilah yang kemudian menjadi dasar utama dikembangkannya strategi pembelajaran 'black tea' dalam pembelajaran matematika. Seperti yang sudah dijelaskan sebelumnya, 'black tea' merupakan kesalahan-kesalahan yang biasanya dilakukan guru pada saat pembelajaran. Untuk lebih operasionalnya, akan sajikan contoh atau ilustrasi sederhana mengenai kesalahan guru dalam memberikan nilai phi $(\pi)$ ketika sedang membahas soal di papan tulis. Kesalahan yang biasanya terjadi adalah nilai $\pi$ yang dituliskan guru sebesar 3,16; bukan 3,14 (meskipun nilai ini pun adalah nilai iterasi).

Siswa yang sudah mengetahui nilai $\pi$ yang sebenarnya pasti akan langsung memberikan respon berkaitan dengan kesalahan tersebut (meskipun ada jeda waktu bagi siswa untuk menyadari kesalahan guru). Biasanya siswa mengkonfirmasi kesalahan tersebut dengan teman sejawat atau dengan membuka buku (paket atau catatan). Setelah siswa yakin bahwa guru benar-benar melakukan kesalahan, biasanya siswa akan meminta konfirmasi dari guru dengan memberitahukan bahwa sepertinya guru mengalami kekeliruan dalam menulis nilai $\pi$. Guru yang diingatkan oleh siswa pun kemudian akan mengkonfirmasi kesalahannya dengan dua respon. Respon pertama, guru biasanya langsung 
mengakui kesalahan yang dilakukan untuk kemudian mengganti nilai $\pi$ tersebut. Respon kedua, guru biasanya akan membalikkan situasi tersebut kepada siswa. Guru biasanya meminta siswa untuk mengkonfirmasi anggapannya dengan meminta siswa untuk membuka buku paket atau catatan untuk meyakinkan anggapannya. Setelah dikonfirmasi kesalahannya, barulah guru memperbaiki kesalahan tersebut dengan tidak lupa membubuhkan kalimat seperti yang sudah dipaparkan sebelumnya: "oh, itu sengaja, untuk menguji kalian saja, apakah kalian memperhatikan atau tidak."

Dari dua respon guru tersebut, respon yang paling diharapkan dilakukan guru dalam pembelajaran adalah respon yang kedua. Hal ini disebabkan karena respon kedua tersebut akan mampu membuat siswa mengulang lagi kegiatan pembelajarannya (belajar kembali) dan mengetahui (memantapkan) nilai $\pi$ yang sebenarnya. Biasanya siswa pun akan menjadi lebih kuat dalam mengingat nilai $\pi$. Selain membantu siswa dalam mengingat atau mengetahui nilai $\pi$, perhatian siswa pun pada saat kegiatan konfirmasi kesalahan akan semakin bagus. Siswa yang biasanya tidak memperhatikan terkadang memperhatikan dan memberikan respon berkaitan dengan kesalahan yang dilakukan guru. Selanjutnya, ada dua poin penting yang bisa dipetik dari contoh tersebut, yaitu: (1) pemahaman siswa mengenai nilai $\pi$ semakin kuat dan (2) perhatian siswa dan keaktifan terhadap kegiatan pembelajaran semakin baik.

Merujuk pada kebermanfaatan di atas, maka penulis beranggapan bahwa kesalahan yang dilakukan guru justru merupakan suatu berkah bagi pembelajaran. Guru bisa menjadikan kesalahan tersebut sebagai suatu strategi yang justru akan mampu memunculkan pengalaman baru bagi siswa yang kemudian berdampak pada pengembangan kompetensi siswa. Bahkan, ilustrasi contoh sederhana yang sudah dipaparkan di atas mampu mengeksplorasi dua ranah tujuan pembelajaran matematika, yaitu ranah kognitif (pemahaman) dan ranah afektif (perhatian dan keaktifan siswa) (Bolin, Khramtsova, \& Saarnio, 2005; Weisberg, Schinazi, Newcombe, Shipley, \& Epstein, 2014) .

Sebelum membuat definisi mengenai strategi pembelajaran 'black tea', penulis akan mencoba untuk mengeksplorasi respon pertama yang sudah disebutkan di atas ketika guru pertama kali diingatkan oleh siswa. Guru yang 
memberikan respon pertama dengan langsung mengubah nilai $\pi$ cenderung tidak memanfaatkan situasi untuk mencoba membuat perhatian siswa menjadi lebih terhadap pembelajaran. Selain itu, guru tidak berusaha mengkonfirmasi nilai yang diberikan siswa, bisa jadi nilai yang diberikan siswa bukan nilai yang sebenarnya. Pada intinya, respon yang pertama tidak bisa dijadikan suatu strategi karena terdapat kekurangan dalam respon tersebut.

Berdasarkan uraian di atas, maka penulis membuat suatu rumusan bahwa strategi pembelajaran 'black tea' haruslah mampu memanfaatkan kesalahan atau kekeliruan guru untuk menjadikan suatu strategi atau umpan-balik terhadap proses pembelajaran. Selain itu, strategi tersebut haruslah melalui suatu proses konfirmasi pengetahuan oleh siswa atas revisi yang diberikan. Oleh karena itu, yang dimaksudkan dengan strategi pembelajaran 'black tea' oleh penulis adalah cara yang dilakukan guru dalam mengembangkan kompetensi siswa dengan memanfaatkan kesalahan atau kekeliruan yang biasa dilakukan guru pada saat proses pembelajaran.

Selanjutnya, ada catatan penting yang harus diperhatikan guru dalam strategi pembelajaran 'black tea', yaitu kesalahan yang dilakukan guru haruslah 'by scenario'. Artinya, strategi ini tidak serta-merta memanfaatkan semua kesalahan guru dalam konteks alamiah. Guru bisa saja melakukannya dalam konteks alamiah tetapi bisa jadi hasil strategi pembelajaran tersebut tidak akan maksimal. Bisa jadi, kesalahan yang dilakukan guru adalah kesalahan pada konsep yang sama sehingga tidak ada peningkatan kompetensi siswa yang bisa dimunculkan. 'By scenario' yang dimaksudkan dalam hal ini adalah kesalahan yang dilakukan oleh guru haruslah 'disengaja'. Hal ini dimaksudkan agar guru bisa memastikan tujuan pelaksanaan strategi pembelajaran tersebut. 'Disengaja' bisa juga diartikan 'direncanakan'. Artinya, kesalahan yang dilakukan guru haruslah melalui proses perencanaan yang matang, baik yang berkaitan dengan pada konsep apa dan kapan melakukan kesalahan, maupun yang berkaitan dengan tindak lanjut atas kesalahan yang dilakukan guru. Perencanaan yang matang merupakan unsur penting yang tidak bisa dipisahkan dalam strategi pembelajaran 'black tea' (Rice, O'Connor, \& Pierantozzi, 2008). Misalkan, seperti contoh di atas guru ingin mengetahui pemahaman siswa mengenai nilai $\pi$, maka guru 
haruslah melakukan kesalahan secara sengaja dalam menuliskan nilai $\pi$ pada saat proses pembelajaran.

Pertanyaan baru pun muncul ketika ada istilah 'by scenario' pada stretagei pembelajaran 'black tea'. Pada konsep apa saja guru seharusnya melakukan guru melakukan kesalahan? Jawabannya adalah guru sengaja melakukan kesalahan terhadap konsep yang siswa sering mengalami kesalahan dalam mengaplikasikan konsep tersebut. Siswa bisa saja melakukan kesalahan dalam hal menuliskan nilai sebenarnya dari suatu variabel matematika tertentu, menuliskan rumus matematika, menggunakan operasi yang tidak tepat, hasil perhitungan yang salah, dan lain sebagainya. Hal ini kemudian menuntut sebelum menerapkan strategi pembelajaran 'black tea', guru haruslah melakukan suatu analisis pendahuluan mengenai learning obstacle apa saja yang dialami siswa pada saat pelaksanaan pembelajaran matematika. Berdasarkan hasil analisis itulah guru kemudian bisa membuat skenario kesalahan pada konsep-konsep yang menjadi learning obstacle bagi siswa. Analisis awal memegang peranan penting dalam strategi pembelajaran 'black tea' karena dengan adanya analisis tersebut akan mampu memetakan learning obstacle-learning obstacle apa yang dialami siswa di kelas. Hal inilah yang kemudian menjadi dasar pemilihan konsep atau topik yang akan dijadikan aspek kesalahan guru (Gersten, Jordan, \& Flojo, 2005).

Sebenarnya, strategi pembelajaran 'black tea' benar-benar menampilkan peran guru sebagai actor yang bertindak seolah-olah salah dan berusaha memperbaiki kesalahan. Padahal, jika merujuk pada sebab pelaksanaan strategi ini adalah adanya kesalahan yang dilakukan siswa. Guru berusaha untuk mencoba memperbaiki kesalahan siswa dengan mengkambing-hitamkan dirinya untuk melakukan kesalahan demi perbaikan kesalahan yang dilakukan oleh siswa. Hal ini dilakukan guru semata-mata demi perbaikan dan pengembangan kompetensi siswa ke arah yang lebih baik. Analisis pendahulan adalah poin penting yang merupakan inti dari strategi pembelajaran 'black tea'.

Berdasarkan uraian di atas, maka penulis mencoba untuk menyimpulkan bahwa setidaknya ada lima rangkaian kegiatan yang harus dilakukan guru pada saat menerapkan strategi pembelajaran 'black tea', antara lain: (1) Guru melakukan analisis pendahuluan mengenai learning obstacle apa saja yang 
dialami siswa dalam pembelajaran matematika; (2) Guru sengaja melakukan kesalahan pada saat proses pembelajaran; (3) Guru memastikan siswa menyadari bahwa guru melakukan kesalahan; (4) Guru meminta siswa untuk mengkonfirmasi perbaikan yang diberikan; dan (5) Guru bersama-sama dengan siswa membuat kesimpulan perbaikan atas kesalahan yang dilakukan guru.

Sebelum mendeskripsikan lebih lanjut mengenai strategi pembelajaran 'black tea', coba bacalah kembali lima rangkaian kegiatan di atas. Apakah ada pertanyaan baru yang muncul? Jawabannya adalah “iya." Beberapa pertanyaan yang bisa muncul adalah bagaimana jika siswa tidak menyadari bahwa guru melakukan kesalahan? Jawaban sederhana untuk pertanyaan ini adalah ketika siswa tidak sadar akan kesalahan guru, maka guru harus memegang peranan untuk menyadarkan siswa atas kesalahan tersebut. Guru bisa menanyakan beberapa pertanyaan kepada siswa, seperti "Apakah kalian yakin dengan jawaban ini? Apakah tidak ada konsep atau langkah-langkah yang salah dalam jawaban ini?” Guru kemudian bisa meminta siswa untuk mengecek kembali semua langkah dan konsep yang digunakan dalam jawaban tersebut. Hal ini dimaksudkan untuk memastikan bahwa siswa menemukan kesalahan dalam pengerjaan soal. Pada akhirnya, siswa pun akan menemukan kesalahan dalam penjabaran yang diberikan guru.

\section{Hubungan Strategi Pembelajaran 'Black Tea' dengan Kemampuan Matematis Siswa}

Proses menemukan atau menyadari kesalahan guru adalah salah satu rangkaian kegiatan yang memiliki banyak manfaat dalam mengembangkan kemampuan matematis siswa, seperti pengembangan kesadaran metakognitif siswa. Siswa menjadi terlatih dalam menyadari informasi apa yang dilewatkan dan berusaha memilih strategi terbaik dalam memperbaiki kesalahan tersebut (Schraw \& Dennison, 1994). Hal ini disebabkan karena kesadaran metakognitif berkaitan dengan kesadaran siswa mengenai proses berpikir dan kemampuannya untuk mengontrol proses berpikir tersebut. Proses berpikir tersebut bisa juga dikaitkan dengan kemampuan siswa dalam memahami konteks yang dialami siswa selama proses pembelajaran (Isnawan, 2015, 2019). Selain kesadaran metakognitif, ada beberapa kompetensi matematika lain yang sampai saat ini 
penulis catat mampu dikembangkan oleh strategi pembelajaran 'black tea', seperti kemampuan penalaran matematis, khususnya indikator 'memeriksa validitas argumen' (Rizqi \& Surya, 2017) dan kemampuan pemecahan masalah matematika, khususnya indikator 'mengecek kembali' (Novriani \& Surya, 2017; Rohmah \& Sutiarso, 2018).

Sebelum membahas hubungan strategi pembelajaran 'black tea' dengan kemampuan pemecahan masalah matematika, terlebih dahulu akan disajikan konsep mengenai masalah dalam matematika. Masalah dalam matematika bisa diartikan sebagai soal yang tidak bisa diselesaikan oleh siswa. Soal tersebut bisa bermacam-macam, bisa jadi soal tersebebut adalah soal yang berkaitan dengan soal cerita dan bisa jadi soal tersebut merupakan soal yang benar-benar berbentuk murni matematika. Pada intinya, masalah yang dimaksudkan dalam hal ini adalah ketika siswa menemukan suatu soal, baik cerita, maupun matematika dan siswa tidak mampu untuk menyelesaikannya, maka soal tersebut bisa diartikan sebagai masalah. Pertanyaan selanjutnya kemudian muncul, apakah suatu soal akan menjadi masalah bagi siswa? Jawabannya adalah "belum tentu." Siswa memiliki kompetensi yang berbeda-beda oleh karena itu suatu soal bisa jadi menjadi masalah bagi siswa tertentu dan bisa jadi bukan merupakan masalah bagi siswa yang lain (Novriani \& Surya, 2017; Phonapichat, Wongwanich, \& Sujiva, 2014).

Bagaimana cara mengetahui suatu soal merupakan masalah atau tidak? Guru bisa mengetahui suatu soal atau tidak dengan memberikan siswa soal tes yang berkaitan dengan konsep matematika tertentu. Guru kemudian memeriksa soal tersebut, mngidentifikasi, dan menyimpulkan mengenai konsep apa saja, soal-soal apa saja, dan jenis soal yang seperti apa yang cenderung menjadi masalah bagi siswa dalam pembelajaran matematika. Hal ini kemudian mengindikasikan bahwa untuk bisa mengetahui apakah suatu soal merupakan masalah atau tidak, maka guru melakukan analisis awal mengenai kemampuan pemahaman konsep siswa (Novriani \& Surya, 2017). Selain itu, analisis awal tersebut pun bisa dijadikan acuan bagi pemilihan strategi pembelajaran 'black tea' dalam pembelajaran matematika. Atau dengan kata lain, strategi pembelajaran 'black tea' memiliki keterkaitan dengan masalah dalam konteks kemampuan pemecahan masalah. 
Pertanyaan selanjutnya, apakah suatu konteks matematika bisa menjadi masalah bagi siswa? Jawabannya adalah "iya," hal ini dikarenakan ketika siswa tidak bisa menterjemahkan secara langsung suatu konteks, maka bisa jadi konteks matematika tersebut adalah masalah bagi siswa sehingga siswa haruslah melakukan analisis berlanjut atas konteks matematika tersebut. Siswa bisa jadi menanyakan kepada guru perihal konteks tersebut dan siswa bisa jadi mencari referensi lain berkaitan dengan maksud dari konteks matematika tersebut. Oleh karena itu, ada dua jenis masalah matematika yang dihadapi siswa, yaitu: soal matematika dan konteks matematika.

Kemampuan pemecahan masalah matematika adalah kemampuan peserta didik dalam menyelesaikan masalah (soal atau konteks) matematika yang dihadapinya. Apakah ketika siswa sudah mampu menyelesaikan masalah siswa bisa dikatakan memiliki kemampuan pemecahan masalah? Jawabannya adalah "belum tentu." Hal ini disebabkan karena dalam kemampuan pemecahan masalah, bukan hanya hasil akhir yang menjadi aspek yang dinilai, melainkan juga aspek proses menyelesaikan masalah. Artinya, siswa dalam menyelesaikan masalah haruslah mampu menyelesaikan masalah tersebut dengan menggunakan langkahlangkah penyelesaian masalah. Sebagai contoh, siswa bisa saja mampu menyelesaikan masalah dengan hasil akhir yang benar dengan menggunakan triktrik matematika. Akan tetapi, permasalahannya adalah apakah trik-trik matematika tersebut mampu menjamin konsep matematika yang benar? Jawabannya pasti "tidak." Oleh karena itu, maka kemampuan pemecahan masalah matematika haruslah memuat langkah-langkah pemecahan masalah dengan menggunakan konsep matematika yang benar.

Ada beberapa indikator kemampuan pemecahan masalah, antara lain: mengidentifikasi masalah, menyusun rencana strategi pemecahan masalah, menerapkan strategi pemecahan masalah, dan mengecek kembali hasil dan proses pemecahan masalah (Novriani \& Surya, 2017). Semua langkap tersebut haruslah mampu diperlihatkan siswa pada saat menyelesaikan masalah sehingga siswa mampu dikatakan memiliki kemampuan pemecahan masalah matematika yang baik . 
Perhatikan kembali rangkaian kegiatan strategi pembelajaran 'black tea', kemampuan pemecahan masalah siswa akan mulai digali pada dimulai dari kegiatan ketiga sampai dengan kegiatan kelima. Pada kegiatan ketiga guru memastikan siswa menyadari bahwa guru melakukan kesalahan. Pada tahapan ini, siswa akan mencoba mencari kesalahan yang dilakukan guru. Siswa tidak secara otomatis menemukan kesalahan yang dilakukan guru sehingga membutuhkan analisis lanjutan atas situasi yang diberikan guru. Ketika siswa tidak bisa menemukan langsung kesalahan guru, maka bisa dikatakan bahwa konteks matematika yang disajikan guru menjadi suatu masalah bagi siswa.

Ketika siswa sudah mengetahui kesalahan yang dilakukan guru, siswa diminta oleh guru untuk mengkonfirmasi apakah memang benar guru melakukan kesalahan dan guru meminta siswa untuk melakukan perbaikan atas kesalahan tersebut. Memperbaiki kesalahan guru bukanlah perkara mudah. Oleh karena itu, siswa diminta untuk memanfaatkan interaksi dengan siswa lain dan dengan sumber belajar yang dimilikinya, seperti buku catatan dan buku paket. Siswa kemudian akan mencoba memperbaiki kesalahan yang dilakukan guru dengan menggunakan strategi pemecahan masalah matematika tertentu untuk memperbaiki kesalahan guru. Guru dan siswa kemudian dalam rangkaian kegiatan kelima strategi pembelajaran 'black tea' akan membuat kesimpulan perbaikan atas kesalahan yang dilakukan.

Hampir sama dengan kemampuan pemecahan masalah, untuk kemampuan penalaran matematis siswa akan mampu berkembang pada rangkaian kegiatan ketiga pada strategi pembelajaran 'black tea'. Hal ini disebabkan karena salah satu bentuk indikator dalam penalaran matematis (memeriksa validitas argumen) memiliki rincian kegiatan yang hampir sama dengan rangkaian ketiga pada strategi pembelajaran 'black tea'. Siswa ketika ingin mengetahui kesalahan oleh guru secara otomatis akan memeriksa setiap langkah pengerjaan guru sehingga pada akhirnya akan menemukan kesalahan yang dimaksudkan. Kegiatan meriksa itu pun haruslah dilandasi dengan konsep matematika yang bagus dari siswa (NCTM, 2000).

Sebagai tambahan untuk kesadaran metakognitif siswa yang sudah dijelaskan sebelumnya, beberapa indikator kesadaran metakognitif mampu 
dimunculkan oleh strategi pembelajaran 'black tea', seperti pengetahuan prosedural dan monitoring. Pengetahuan prosedural berkaitan dengan pengetahuan siswa mengenai cara menggunakan suatu konsep matematika tertentu. Pengetahuan prosedural ini kemudian dimunculkan dalam rangkaian ketiga strategi pembelajaran 'black tea', sedangkan indikator monitoring secara tidak langsung akan muncul pada saat siswa memastikan kesalahan guru dengan memanfaatkan pengetahuan yang dimilikinya (Schraw, 1998).

Berdasarkan uraian di atas, maka diharapkan bahwa dengan implementasi strategi pembelajaran 'black tea' dan pengaruhnya terhadap kemampuan matematis siswa akan mampu meminimalisir learning obstacle yang dialami siswa, khususnya dalam pembelajaran matematika. Untuk lebih memantapkan pemahaman dan membuktikan keefektifan strategi pembelajaran 'black tea', maka penulis berharap adanya tindak lanjut untuk melakukan penelitian quasiexperiment dengan metode mix-method untuk membuktikan keefektifan strategi pembelajaran tersebut dalam konteks pembelajaran.

\section{Filosofis Strategi Pembelajaran 'Black Tea'}

Meskipun, dalam ruang lingkup strategi pembelajaran, strategi pembelajaran 'black tea' didasarkan pada dua paradigma utama, yaitu: interpretive and critical pedagogy. Hal ini disebabkan karena strategi pembelajaran 'black tea' dalam implementasinya mencoba untuk menggali hakikat dalam suatu realitas, yaitu learning obstacle yang dialami siswa untuk kemudian dimaknai dan diberikan alternatif solusi dalam bentuk strategi pembelajaran (interpretif). Critical pedagogy karena strategi pembelajaran 'black tea' berpegangan pada asumsi bahwa pengetahuan atau konsep matematika haruslah dikreasi ulang karena pada dasarnya pengetahuan tidak bersifat absolut (Suryadi, 2019b). Selain itu, strategi pembelajaran 'black tea' dalam implementasinya memanfaatkan beberapa bagian dari model desain pembelajaran didactical design research (DDR). Hal ini disebabkan karena pada beberapa langkah awal pembelajaran terdapat integrasi langkah DDR, seperti: analisis situasi didaktis sebelum pembelajaran atau analisis prospektif, khususnya pada saat mengidentifikasi learning obstacle yang dimiliki siswa (Suryadi, 2019a). 


\section{Kesimpulan dan Saran}

Berdasarkan uraian di atas, maka dapat disimpulkan bahwa strategi pembelajaran 'black tea' adalah strategi pembelajaran yang memanfaatkan kesalahan (by scenario) yang dilakukan oleh guru pada saat pembelajaran demi mengembangkan kompetensi yang dimiliki siswa. Adapun rangkaian kegiatan dalam strategi pembelajaran 'black tea' adalah (1) Guru melakukan analisis pendahuluan mengenai learning obstacle apa saja yang dialami siswa dalam pembelajaran matematika; (2) Guru sengaja melakukan kesalahan pada saat proses pembelajaran; (3) Guru memastikan siswa menyadari bahwa guru melakukan kesalahan; (4) Guru meminta siswa untuk mengkonfirmasi perbaikan yang diberikan; dan (5) Guru bersama-sama dengan siswa membuat kesimpulan perbaikan atas kesalahan yang dilakukan guru. Selain itu, strategi pembelajaran 'black tea' secara kerangka teori diharapkan mampu mengembangkan kompetensi matematis siswa, seperti: pemahaman konsep, kemampuan pemecahan masalah matematika, kemampuan penalaran matematis, kesadaran metakognitif, dan aspek afektif siswa (persepsi dan keaktifan).

Oleh karena tulisan ini baru sampai pada tahapan mengkaji kerangka teoritis strategi pembelajaran 'black tea', diharapkan bagi pembaca atau peneliti untuk membuktikan atau mengkonfirmasi dalam bentuk penelitian mengenai apakah strategi pembelajaran 'black tea' bisa berpengaruh terhadap pengembangan kompetensi matematis siswa. Diharapkan hasil penelitian tersebut kemudian akan mampu memperkuat keyakinan bahwa strategi pembelajaran 'black tea' akan mampu meminimalisir learning obstacle yang dialami siswa di sekolah dan stretagi pembelajaran ini juga diharapkan mampu mengembangkan kompetensi matematis siswa secara maksimal. Selain itu, karena strategi pembelajaran ini masih sangat baru, maka diharapkan bagi pembaca untuk memberikan pertanyaan, kritik yang membangun, dan saran berkaitan dengan strategi pembelajaran 'black tea'.

\section{Daftar Pustaka}

Bolin, A. U., Khramtsova, I., \& Saarnio, D. (2005). Using Student Journals to Stimulate Authentic Learning: Balancing Bloom's Cognitive and Affective Domains. Teaching of Psychology, 32(3), 154-159. 
https://doi.org/10.1207/s15328023top3203_3

Boyd, P., \& Ash, A. (2018). Mastery mathematics: Changing teacher beliefs around in-class grouping and mindset. Teaching and Teacher Education, 75, 214-223. https://doi.org/10.1016/j.tate.2018.06.016

Dunbar, C. (2004). Best Practices in Classroom Management. Best Practices in Classroom Management, (October), 32.

Gersten, R., Jordan, N. C., \& Flojo, J. R. (2005). Early Identification and Mathematics Difficulties. Journal of Learning Disabilities, 38(4), 293-304. https://doi.org/10.1177\%2F00222194050380040801

Hanushek, E. A., Peterson, P. E., Woessmann, L., \& School, H. K. (2010). Harvard's Program on Education Policy and Governance \& Education Next Taubman Center for State and Local Government. Cambridge: Harvard Kennedy School.

Hanushek, E. A., \& Rivkin, S. G. (2006). Chapter 18 Teacher Quality. Handbook of the Economics of Education, 2(06), 1051-1078. https://doi.org/10.1016/S1574-0692(06)02018-6

Henning, S. M., Niu, Y., Lee, N. H., Thames, G. D., Minutti, R. R., Wang, H., ... Heber, D. (2004). Bioavailability and antioxidant activity of tea flavanols after consumption of green tea, black tea, or a green tea extract supplement. American Journal of Clinical Nutrition.

Hwang, J., Choi, K. M., Bae, Y., \& Shin, D. H. (2018). Correction to: Do Teachers' Instructional Practices Moderate Equity in Mathematical and Scientific Literacy?: An Investigation of the PISA 2012 and 2015 (International Journal of Science and Mathematics Education, (2018), 16, S1, (25-45), 10.1007/s10763-0. International Journal of Science and Mathematics Education, 16(8), 1629-1631. https://doi.org/10.1007/s10763018-9918-7

Isnawan, M. G. (2015). Pengkategorian Kesadaran Metakognitif Mahasiswa pada Pembelajaran Aljabar Linier di AMIKOM Mataram. Seminar Nasional Matematika Dan Pendidikan Matematika UNY, 187-192. Yogyakarta: Universitas Negeri Yogyakarta.

Isnawan, M. G. (2019). The effect of metacognitive awareness toward lecturer's peformance. Math Didactic: Jurnal Pendidikan Matematika. https://doi.org/10.33654/math.v5i2.520

Maylor, U. (2012). r P Fo r R w On ly. Ethic and Racial Studies, 32(2), 369-387. https://doi.org/10.1080/01446193.2012.693189

NCTM. (2000). Principles and Standards for School Mathematics. Reston: The 
National Council of Teacher of MAthematics, Inc.

Niess, M. L. (2005). Preparing teachers to teach science and mathematics with technology: Developing a technology pedagogical content knowledge. Teaching and Teacher Education, 21(5), 509-523. https://doi.org/10.1016/j.tate.2005.03.006

Novriani, M., \& Surya, E. (2017). Analysis Of Student Difficulties In Mathematics Problem Solving Ability At Mts Swasta Ira Medan. International Journal of Sciences: Basic and Applied Research (IJSBAR), 33(03), 1-14.

Oktiningrum, W., Zulkardi, \& Hartono, Y. (2016). Developing PISA-like mathematics task with Indonesia natural and cultural heritage as context to assess students' mathematical literacy. Journal on Mathematics Education, $7(1), 1-8$.

Phonapichat, P., Wongwanich, S., \& Sujiva, S. (2014). An Analysis of Elementary School Students' Difficulties in Mathematical Problem Solving. Procedia - Social and Behavioral Sciences, 116(October 2015), 3169-3174. https://doi.org/10.1016/j.sbspro.2014.01.728

Priyani, H. A., \& Ekawati, R. (2018). Error analysis of mathematical problems on TIMSS: A case of Indonesian secondary students. IOP Conference Series: Materials Science and Engineering, 296(1). https://doi.org/10.1088/1757899X/296/1/012010

Rice, M. P., O’Connor, G., \& Pierantozzi, R. (2008). Implementing a learning plan to counter project uncertainty. IEEE Engineering Management Review, 36(2), 92-102. https://doi.org/10.1109/EMR.2008.4534821

Rizqi, N. R., \& Surya, E. (2017). An Analysis of Students' Mathematical Reasoning Ability in VIII Grade of Sabilina Tembung Junior High School. Ijariie, 3(2), 3527-3533.

Rohendi, D., \& Dulpaja, J. (2013). Connected Mathematics Project (CMP) Model Based on Presentation Media to the Mathematical Connection Ability of Junior High School Student. 4(4), 17-22.

Rohmah, M., \& Sutiarso, S. (2018). Analysis problem solving in mathematical using theory Newman. Eurasia Journal of Mathematics, Science and Technology Education, 14(2), 671-681. https://doi.org/10.12973/ejmste/80630

Schraw, G. (1998). <Schraw1998-Meta.pdf>. 113-125. https://doi.org/10.1023/A:1003044231033

Schraw, G., \& Dennison, R. S. (1994). Assessing Metacognitive Awareness. 
Contemporary Educational Psychology, 19, 460-475.

Selvi, K. (2010). Teachers' competencies. Cultura. International Journal of Philosophy of Culture and Axiology, 7(1), 167-175. https://doi.org/10.5840/cultura20107133

Stacey, K. (2011). The PISA view of mathematical literacy in Indonesia. Journal on Mathematics Education, 2(2), 95-126.

Surya, E., Putri, F. A., \& Mukhtar. (2017). Improving mathematical problemsolving ability and self-confidence of high school students through contextual learning model. Journal on Mathematics Education, 8(1), 85-94.

Suryadi, D. (2019a). DDR dalam Implementasi Kurikulum. In Penelitian Desain Didaktis (DDR) dan Implementasinya (pp. 51-75).

Suryadi, D. (2019b). Landasan Filosofis Penelitian Desain Didaktis (DDR). In Landasan Filosofis Penelitian Desain Didaktis (DDR) (pp. 5-17). Bandung: Pusat Pengembangan DDR Indonesia.

Telkamp, G. J. (1981). Note to users. Itinerario, 5, 68-69. https://doi.org/10.1017/S0165115300023299

van de Pol, J., Volman, M., \& Beishuizen, J. (2010). Scaffolding in teacherstudent interaction: A decade of research. Educational Psychology Review, 22(3), 271-296. https://doi.org/10.1007/s10648-010-9127-6

Weisberg, S. M., Schinazi, V. R., Newcombe, N. S., Shipley, T. F., \& Epstein, R. A. (2014). Variations in cognitive maps: Understanding individual differences in navigation. Journal of Experimental Psychology: Learning Memory and Cognition, 40(3), 669-682. https://doi.org/10.1037/a0035261

Zan, R., \& Martino, P. (2007). Attitudes towards mathematics: Overcoming positive/negative dichotomy. The Montana Mathematics Enthusiasts, 157$168 . \quad$ Retrieved from http://www.math.umt.edu/TMME/Monograph3/Zan_Monograph3_pp.157_1 68.pdf 